Bidik

Vol. 1 No. 1 Oktober 2020

$43-47$

\title{
Pelatihan Penulisan Skenario Film Untuk Siswa SMK Muhammadiyah 2 Pekanbaru
}

\author{
M.Kafrawi *, Evizariza, R. Syamsidar \\ Fakultas Ilmu Budaya, Universitas Lancang Kuning \\ *Email : hangkaf74@yahoo.com
}

\begin{abstract}
In modern times it is marked by the discovery of advanced technology, it requires a creative young generation, so that they can compete in accordance with the demands of the times. One of the areas of creativity that gets that place is creativity in creating films. Films can be used as a place to express feelings, as well as being used as a product promotion or area where the film's work is produced. This fact is strengthened by the increasing penetration of social media such as YouTube, Facebook, Twitter, and Instagram. To produce good film work, a reliable screenwriter is also needed. For this reason, training in writing film scenarios is required. This first stage scenario writing training was conducted at SMK Mubammadiyah 2 Pekanbaru. The younger generation, in this case, vocational high school students and the equivalent are a very potential age to be trained to write good and correct scenarios. With scenario writing training, at least SMK students can get to know what a scenario is and at the same time be able to practice writing good and correct scenarios.
\end{abstract}

Keywords: Scenarios, Writing, Students

\begin{abstract}
Abstrak
Di zaman modern ini ditandai dengan ditemukan teknologi canggih, diperlukan generasi muda yang kreatif, sehingga dapat bersaing sesuai dengan tuntutan zaman. Salah satu bidang kreativitas yang mendapat tempat itu adalah kreativitas menciptakan film. Film dapat dijadikan wadah mengekspresikan perasaan, sekaligus dapat dijadikan promosi produk atau daerah di mana karya film itu dihasilkan. Kenyataan ini diperkuat dengan semakin merasuknya media sosial seperti youtube, facebook, twiter, dan instragram. Untuk menghasilkan karya film yang baik, maka diperlukan penulis skenario yang handal pula. Untuk itulah diperlukan pelatihan menulis skenario film. Pelatihan menulis skenario tahap pertama ini dilakukan di SMK Muhammadiyah 2 Pekanbaru. Generasi muda, dalam hal ini, siswa-siswa SMK sederajat merupakan usia yang sangat potensial untuk dilatih menulis skenario yang baik dan benar. Dengan pelatihan menulis skenario, paling tidak siswa SMK dapat mengenal lebih dekat apa itu skenario dan sekaligus dapat mempraktikkan menulis skenario yang baik dan benar.
\end{abstract}

Kata Kunci: Skenario, Menulis, Siswa

\section{Pendahuluan}

Sebagaimana keterampilan menulis lainnya, menulis skenario film merupakan bagian penting dalam menuangkan gagasan atau pun ide. Banyak manfaat dari menulis. Beberapa diantara manfaat tersebut menurut Akhadiah dkk (1998: 1-2) adalah membantu kita mengenal kemampuan dan potensi diri, mengembangkan berbagai gagasan, belajar mengorganisasikan gagasan secara sistematik dan dapat mengungkapkannya secara tersurat, membuat kita dapat meninjau serta menilai 
gagasan kita sendiri secara objektif, mendorong kita belajar secara aktif, belajar menganalisis serta membiasakan kita berpikir dan berbahasa secara tertib.

Dari banyak manfaat tersebut salah satu poin utamanya adalah bahwa menulis erat kaitannya dengan pengembangan pikiran dan penyampaian peristiwa. Pelajar sebagai generasi mudadan calon cendekia muda semestinya memang harus aktif dalam menulis. Lewat tulisan, pelajar dapat menyampaikan gagasan-gagasan, pikiran serta pengetahuannya sekaligus dapat menyampaikan peristiwa kepada orang banyak, sehingga bisa dibaca oleh khalayak ramai. Namun, persoalannya banyak pelajar yang kurang mampu menulis dengan baik. Indikasi ini bisa ditemukan dari kurangnya penulis muda Riau yang muncul diberbagai media massa, baik cetak maupun online. Padahal dengan menulis terbuka lowongan pekerjaan yang mampu meningkatkan taraf ekonomi.

Salah satu penyebab dari persoalan ini adalah kekurangpahaman pelajar tentang aktivitas menulis. Selain itu masih kurangnya kurikulum di sekolah dalam mendalami ilmu menulis, khususnya menulis skenario film, sehingga pelajar sangat minin bersentuhan dengan dunia tulis menulis. Tentu saja, kurangnya bersentuhan dengan dunia menulis dan prakteknya di sekolah menyebabkan pelajar kurang tertarik, bahkan cenderung tidak menyukai menulis, khususnya menulis skenario film.

Berdasarkan kondisi tersebut maka kami merasa perlu untuk mengadakan pelatihan menulis, dalam hal menulis skenario, yang ditujukan pada pelajar SMA. Pelajar sebagai objek sasaran dibatasi hanya pada pelajar SMKMuhammadiyah 2 Pekanbaru, Provensi Riau. Pembatasan ini lebih karena alasan keterbatasan kemampuan serta pengefektifan capaian pelatihan.

Permasalahan utama yang dihadapi oleh mitra adalah masih kurangnya kemampuan menulis di kalangan pelajar. Selain itu kurikulum di sekolah sangat minim dalam menulis, khususnya menulis skenario film. Diperlukan kesabaran dan ketelitian dalam memberi materi yangdisampaikan kepada para pelajar. Selama ini menulis menjadi hal yang menakutkan bagi pelajar.

\section{Pedekatan Pelaksanaan Program}

Kegiatan $\mathrm{I}_{\mathrm{b}} \mathrm{m}$ dilakukan kepada pelajar SMK Muhammadiyah 2 Pekanbaru, Riau. Jumlah pelajar yang akan mengikuti pelatihan ini 30 orang. Pelaksanaan kegiatan meliputi beberapa tahap sebagai berikut.

1. Pelatihan mengetahui definisi skenario film

Pada tahap ini, tim melakukan transfer informasi mengenai definisi skenario film. Pada tahap ini juga tim memberikan pemahaman tentang pengertian berbagai bentuk skenario film.

Materi yang disampaikan pada tahap ini adalah:

- Definisi skenario film

- Mengenalkan bentuk-bentuk skenario film

- Peralatan yang diperlukan pada tahap ini adalah: 
- Skenario film

- Lembar Kerja

2. Pelatihan mengetahui ciri dan bentuk film

Pada tahap ini, tim melakukan transfer informasi mengenai ciri dan bentuk film. Materi yang disampaikan pada tahap ini adalah:

- Ciri film

- Bentuk-bentuk film

Peralatan yang dibutuhkan pada tahap ini adalah:

- Contoh film

- Lembar Kerja

3. Pelatihan menghasilkan karya tulis, khususnya skenario film

Pada tahap ini, tim melakukan transfer informasi mengenai cara menulis skenario film. Tahap ini adalah tahap praktek. Masing-masing pelajar ditugaskan untuk membuat skenario film pendek. Setelah itu dilakukan evaluasi bersama atas karya yang telah mereka buat.

\section{Pelaksanaan Program}

Kegiatan pelatihan direncanakan dilaksanakan pada tanggal 14 Desember 2019, pukul 08.00-12.30 WIB. Pelaksanaan kegiatan bertempat di ruang kelas SMK Muhammadiyah 2 Pekanbaru, Riau.

Kegiatan pelatihan ini menunjukan hasil yang bagus bagi peserta, baik dari sisi kuantitatif maupun kualitatif. Dari sisi kuantitatif menunjukan jumlah peserta yang hadir berjumlah 30 orang, sesuai dengan target.Sisi kuantitatif menunjukan bahwa peserta pelatihan memiliki pemahaman mengenai fungsi dan manfaat menulis skenario.Selainitu, merekasudah memahami tentang skenario, namun dalam praktek menulis belum mengetahui secara mendalam.

Selama pelatihan, peserta juga diberikan pre-test dan post-test untuk mengukur pemahaman dan kepuasan terkait pelatihan ini, berikut tabelnya:

\section{Tabel 1. Hasil Pretest}

\begin{tabular}{|c|c|c|c|c|}
\hline \multicolumn{5}{|c|}{ Pretest } \\
\hline No & Topik Test & $\mathbf{Y a}$ & Tidak & Ragu-ragu \\
\hline 1 & Pengenalan film & 30 & 0 & 0 \\
\hline 2 & $\begin{array}{l}\text { Pernah menulis skenario } \\
\text { film }\end{array}$ & 1 & 29 & 0 \\
\hline 3 & Kemauan belajar menulis & 30 & 0 & 0 \\
\hline 4 & $\begin{array}{l}\text { Keuntungan menulis } \\
\text { skenario film }\end{array}$ & 5 & 25 & 0 \\
\hline 5 & $\begin{array}{l}\text { Keuntungan menulis skenar } \\
\text { Bisa mengekspresikan apa y } \\
\text { Bisa menambah wawasan } \\
\text { Sebagai ajang bisnis, mengal } \\
\text { Dapat dijadikan usaha } \\
\text { Memanfaatkan teknologi y } \\
\text { massa online atau chanel yo }\end{array}$ & $\begin{array}{l}\text { m: } \\
\text { ngin } \\
\text { n kes } \\
\text { sedar }\end{array}$ & bang, & nemiliki media \\
\hline
\end{tabular}


Berdasarkan tabel mengenai pretest di atas, dapat diuraikan bahwa semua peserta pelatihan mengetahui tentang film.Padatopik menulis scenario film cuma 1peserta yang sudah pernah menulis, sementara 29 belum pernah melakukan menulis skenario, namun demikian minat untuk belajr menulis skenario sangat antusias. Kemauan untuk belajar menulis skenario ini seluruh peserta menyanggupi. Peserta juga tidak mengetahui sepenuhnya format menulis scenario.

Untuk lebih mendalam mengetahui terkait menulis skenario dan manfaatnya, dilakukan juga posttest. Dari hasil post-test menunjukkanperbedaan yang signifikandibandingkanhasil pretest. Berikuttabelnya:

Tabel 2. Hasil Postest

\begin{tabular}{|c|c|c|c|c|}
\hline \multicolumn{5}{|c|}{ POSTEST } \\
\hline No & Topik Test & $\mathbf{Y a}$ & Tidak & Ragu-ragu \\
\hline 1 & Pengenalan film & 30 & 0 & 0 \\
\hline 2 & Kemauan belajar menulis & 30 & 0 & 0 \\
\hline 4 & $\begin{array}{l}\text { Keuntungan menulis } \\
\text { skenario film }\end{array}$ & 30 & 0 & 0 \\
\hline 5 & \multicolumn{4}{|c|}{$\begin{array}{l}\text { Keuntungan menulis skenario film: } \\
\text { Bisa mengekspresikan apa yang ingin disampaikan } \\
\text { Bisa menambah wawasan } \\
\text { Sebagaiajangbisnis, mengabarkan kegiatan } \\
\text { Dapat dijadikan usaha } \\
\text { Memanfaatkan teknologi yang sedang berkembang, seperti memiliki media } \\
\text { massa online atau chanel youtube }\end{array}$} \\
\hline
\end{tabular}

Berdasarkan tabel di atas, dapat dijelaskan bahwa topik Pengenalan istilah skenario film, keinginan belajar menulis skenario, sebagian besar pesertamenjawab "ya". Hal ini membuktikan bahwa sebagian besar peserta memiliki kemauan untuk menulis, namun kendala utamnya adalah peserta belum mengenal dan mengetahui cara menulis scenario film.

Merujuk dari hasil isian pretest dan posttest dapat ditarik kesimpulan, bahwa pelatihan ini cukup disambut antusias oleh peserta. Selain ilmu yang didapat, peserta juga memiliki keterampilan untuk menulis scenario film yang dimanfaatkan untuk bertukar informasi, memperoleh pengetahuan, media berekspresi, bahkan sebagai promosi kegiatan dan memperoleh penghasilan.

Luaran yang dicapai dalam kegiatan ini adalah tulisan skenario film dan draft artikel ilmiah. Draft artikel ilmiah terlampir pada Lampiran Artikel Ilmiah. Sedangkan untuk produk menulis skenario film belum semua peserta mampu menghasilkan skenario.

\section{Refleksi Capaian Program}

Pelatihan Penulisan Skenario Film untuk Siswa SMK Muhammadiyah 2 Pekanbaru merupakan upaya mengajak generasi muda membiasakan diri dengan menulis.Dari pelatihan ini dapat disimpulkan bahwa kemauan generasi muda, khususnya siswa SMK Muhammadiyah 2 Pekanbaru memiliki keinginan menulis yang 
tinggi. Hal ini ditandai dengan atusiasnya peserta mengikuti materi yang diberikan dan terjadinya tanya jawab peserta dengan pemateri. Dari pelatihan ini juga terlihat bagatbagat penulis muda yang dapat bersaing melalui karya-karya film nantinya.Walaupun demikian, pelatihan yang singkat ini belum mampu menggali potensi siswa-siswa tersebut lebih dalam lagi.Pelatihan ini juga baru memperkenalkan dasar-dasar penulisan skenario film, bvelum sampai kepada kualitas karya yang dihasilkan.

\section{Penutup}

Sebagai pelatihan dasar dan memiliki waktu yang terbatas, tentu saja belum mendapatkan hasil yang memuaskan.Apalagi untuk menghasilkan karya tulis yang baik diperlukan keberlanjutan dan disiplin. Dari hasil inilah ada beberapa saran yang perlu dipertimbangan, antara lain sebagai berikut:

a. Mengadakan pelatihan berkelanjutan dengan mitra yang sama. Dengan hal ini pengetahuan atau dasar-dasar menulis skenario dapat dilanjutkan, sehingga peserta benar-benar dapat menghasilkan skenario yang berkualitas.

b. Membentuk komunitas penulis skenario muda Riau. Wadah ini dapat digunakan untuk mengadakan diskusi seputar perkembangan film.

c. Melahirkan film bersama.

\section{Daftar Pustaka}

Arswendo Atmowiloto. 2004. Mengarang Itu Gampang. Jakarta: Gramedia Pustaka Utama

Budiman Akbar. 2015. Semua Bisa Menulis Skenario. Jakarta. Esensi.

Misbach Yusra Biran. 1997. Teknik Menulis Skenario Film Cerita. Jakarta. Pustaka jaya

Winna Efendi. 2012. Taktik Menulis. Jakarta: Gagas Media 